\title{
HUKUM PERINDUSTRIAN DALAM PANDANGAN ISLAM
}

\author{
Eghytya Bagaskara \\ Perbankan Syariah \\ Fakultas Ekonomi dan Bisnis Islam \\ UNIVERSITAS ISLAM NEGERI ALAUDDIN MAKASSAR \\ eghytyabagaskara2003@gmail.com
}

\begin{abstract}
ABSTRAK
Bekerja keras adalah cara yang paling efektif untuk memperoleh rahmat Allah, begitulah Rasulullah SAW mengajarkan sejak empat belas abad yang lalu. Industri adalah salah satu manifestasi dari kerja keras. Dan industri adalah cabang ekonomi yang tingkat perkembangan produktivitasnya lebih cepat dari perkembangan tingkat produktivitas keseluruhan cabang ekonomi. Maka peranannya dalam menciptakan produksi dan menciptakan lapangan kerja tentu lebih besar dari keseluruhan cabang ekonomi. Namun, disamping peranannya yang sangat besar terhadap kemajuan sebuah Negara, industry dituduh sebagai penyebab menurunnya nasionalisme sebauah bangsa, industry juga dituduh merugikan sektor pertanian yang karena industrialisasi ribuan hektar lahan pertanian beralih fungsi menjadi sentra-sentra industry. Benarkah tuduhan-tuduhan tersebut? Dan bagaimanakah pandangan Islam terhadap industry dan hubungan industry dengan nasionalisme dan pertanian? Industry sangat dianjurkan dalam Islam, karen industry adalah manifestasi dari kerja keras yang sangat dianjurkan oleh Islam. Usaha industry adalah salah satu bentuk pekerjaan yang sangat dihormati dalam Islam. Namun dalam berindustri, seorang muslim harus menepati aturanaturan Islam, agar tidak menyimpang dari tujuan Islam. Lima prinsip seorang muslim dalam aktifitas ekonominya, yaitu: tauhid uluhiyyah, tauhid rububiyah, istikhlaf, tazkiyatu 1 nafs dan al-falah.
\end{abstract}




\section{PENDAHULUAN}

Industry sangat dianjurkan dalam Islam, karena industry adalah manifestasi dari kerja keras yang sangat dianjurkan oleh Islam. Usaha industry adalah salah satu bentuk pekerjaan yang sangat dihormati dalam Islam.Namun dalam berindustri, seorang muslim harus menepati aturan-aturan Islam, agar tidak menyimpang dari tujuan Islam. Lima prinsip seorang muslim dalam aktifitas ekonominya, yaitu: tauhid uluhiyyah, tauhid rububiyah, istikhlaf, tazkiyatu l nafs dan al-falah. Dalam kaitannya dengan nasionalisme, Islam mengatur bahwa industry yang menyangkut kepentingan negar dan orang banyak, maka industry tersebut harus dimiliki orang banyak dan tidak boleh dimilki pribadi bahkan hak yang diberikan Negara kepada swasta untuk bidang-bidang yang menyangkut hajat hidup orang banyak dapat ditarik kembali dan kembali dikuasai Negara untuk kepentingan masyarakat jika perusahaan swasta tersebutmerugikan masyarakat. Begitu juga petanian yang menjamin pangan masyarakat, maka Negara bertanggungjawab atas keberhasilan dunia pertanian. Tidak boleh ada yang dirugikan, baik pertanian maupun industry, keduanya bisa berjalan bersama dan saling mendukung. ${ }^{1}$

\footnotetext{
Abd Aziz Islahi, Economic Concept of Ibn Taimiyah, (London: The Islamic
} Foundation, 1988). 


\section{Perindustrian di Masa Lalu}

Pada zaman Mamluk, industry sudah mendapatkan perhatian yang besar. Mesir mengembangkan berbagai jenis industry untuk meningkatkan ekonominya5. Pada masa itu, Mesir sangat terkenal dengan produk-produk industry tekstilnya. Industri logam juga sangat berkembang di Mesir. Peralatan-peralatan rumah tangga dari logam berkembang seperti perkembangan ornament-ornamen perhiasan dari emas dan perak. Peninggalan-peninggalan kerangka rumah dari besi dan baja dari Zaman Mamluk sampai sekarang masih tersimpan baik di Arabian Archeological Museum of Cairo. Disamping tekstil dan logam, pada tahun 1870-an, Mesir juga sudah mengembangkan industry kimia, makanan, kulit, perkayuan, batu dan keramik, kaca, dan industry seni grafis dan desain.Pusat industry Mesir pada saat itu adalah Cairo dan Alexandria. Sultan Muhammad Ali dari Kesultanan Turki Usmani juga memandang industry sebagai bagian ekonomi yang sangat penting untuk kesejahteraan rakyat dan kesultanannya. Ia menandatangani kerjasama bidang ekonomi dan industry dengan Kerajaan Inggris (the Anglo-Ottoman Trade Convention) pada tahun 1838, yang diantara isinya adalah peningkatan kerjasama ekspor dan impor antara dua Negara dan aturan proteksi terhadap usaha-usaha industry di Kesultanan Turki Usmani.Hal itulah yang mendasari perkembangan industry modern di Turki. Hanya Istambul dan Izmir yang semula menjadi pusat industry di Turki, tapi kemudian berkembang hampir ke seluruh wilayah Anatolia, termasuk Ankara dan Adana. ${ }^{2}$

2

Abd Aziz Islahi, Economic Concept of Ibn Taimiyah, (London: The Islamic Foundation, 1988). 


\section{Industrialisasi vs Nasionalisme}

Sejarah membuktikan bahwa kegagalan model centrally planned economy telah terjadi dimana-mana, khususnya setelah runtuhnya sosialisme di Eropa Timur. Di pihak lain, banyak Negara berkembang yang berhasil mengalami kemajuan yang sangat pesat sehingga mencapai tingkat New Industrial Countries (NIC's). Mereka berhasil mencapai tarafitu karena berhasil mendorong kekuatan Negara dan kekuatan swasta di Negara-negara tersebut untuk bersinergi membangun perekonomian Negara. Hal ini menunjukkan bahwa keberhasilan ekonomi juga sangat dipengaruhi oleh peran swasta yang efisien dan produktif. "Uruguay Round" yang mengatur tentang peraturan baru perdagangan multilateral menghendaki agar intervensi pemerintah yang terlalu banyak dalam perdagangan internasional dapat dikurangi,sehingga perdagangan bisa berjalan lebih baik. Hal ini merupakan indikasi langkah mundur bagi pengaturan ekonomi oleh pemerintah, dan awal dari renaissance kepercayaan terhadap mekanisme pasar yang akan menentukan kebijakan ekonomi. Aliran ini tidak percaya kepada kemampuan pemerintah untuk mengatur terlalu banyak jalannya perekonomian, dan lebih condong untuk memberi lebih banyak kebebasankepada pasar. ${ }^{3}$

${ }^{3}$ A.L. Udovitch, The Islamic Midle East 700-1900, (New Jersey: The Darwin Press. Inc., 1981). 


\section{Perindustrian Dalam Perspektif Islam}

Islam, menurut para ulama, menawarkan sebuah semangat dan sikap mental agar setiap Muslim selalu berpandangan bahwa kehidupan hari esok harus lebih baik daripada hari ini dengan melalui aktivitas berkarya. Sebagaimana firman Allah dalam At- Taubah [9]: 105 (Dan katakanlah: "Bekerjalah kamu, maka Allah dan Rasulnya serta orang-orang beriman akan melihat pekerjaan itu, dan kamu akan dikembalikan kepada Allah yang mengetahui akan yang ghaib dan yang nyata, lalu diberitakan-Nya kepada kamu apa yang -telah kamu kerjakan), dan bahkan mendorong umat Islam untuk menjadi 'Subjek Perubahan'. Kesadaran untuk berkarya harus berlandaskan semangat tauhid. Sehingga semua aktivitas keseharian setiap Muslim harus diniatkan dan diorientasikan sebagai ibadah kepada Allah SwT (dalam rangka mencarikeridlaan Allah SWT). Sebaliknya, setiap upaya ibadah kepada Allah harus direalisasi dalam bentuk 'karya nyata' yang bernilai positif (amal shalih). Karya, bagi setiap Muslim, adalah ibadah dan ibadah merupakan implementasi dari sikap tauhid. ${ }^{4}$

4

Cameron, Rondo, Lary Neal, a Concise Economic History of the World,

(New York: Oxford Unniversity Press., 2003). 


\section{KESIMPULAN}

Dalam Islam, etika dan moral berperan sangat sentral. Dalam segala aspek ekonomi pun Islam mengatur bahwa etika dan moral harus bisa memerankan perannya dengan baik. Segala jenis aktivitas ekonomi yang bertentangan dengan nilai-nilai etika Islam diharamkan. Dalam bidang industry begitu juga. Bukan hanya keuntungan materi yang di kejar. Dan tanggung jawab moralnya pun bukan hanya kepada manusia, tetapi yang lebih berat adalah tanggung jawab kepada Allah SWT. Keuntungannya pun bukan hanya keuntungan duniawi yang di kejar,tetapi keuntungan duniawi dan ukhrawi. Dalam Islam, industry harus maju dan didukung penuh oleh Negara karena fungsinya yang sangat penting, tapi meskipun demikian tidak boleh ada bidang-bidang lain yang dirugikan, seperti nasionalisme dan pertanian. Semua harus berjalan dan saling mendukung. 


\section{DAFTAR PUSTAKA}

Abd Aziz Islahi, Economic Concept of Ibn Taimiyah, (London: The Islamic Foundation, 1988).

Abdurrahman al-Maliki, Politik Ekonomi Islam, (Bangil: al-Izzah, 2001)

A.L. Udovitch, The Islamic Midle East 700-1900, (New Jersey: The Darwin Press. Inc., 1981).

Boediono, Teori Pertumbuhan Ekonomi, (Yogyakarta: BPFE, 1981).

Cameron, Rondo, Lary Neal, a Concise Economic History of the World, (New York: Oxford Unniversity Press., 2003). 